\title{
General Scientific Analysis of Implementation of Principles of Law in the Contemporary Russian Legal Basis
}

\author{
Dmitri Anatolevich Smirnov* and Konstantin Alexandrovich Strus
}

North - Caucasus Federal University, Stavropol, Russian Federation; monblan@yandex.ru

\begin{abstract}
The purpose of the article is to determine the value of the principles of law in legal acts in contemporary Russia. Scientific results of the article include as follows: a definition of the "legal basis" category is offered within this study; the author's point of view relating to the ensuing debate in scientific publications with respect to the "legal principle" and the "principle of law" categories is determined; such concepts as "principles of law", "general principles of law", "sectoral principles of law", "inter-industry principles of law" are clarified; the impact of the principles of law on the formation of the system of legal acts is examined, their value and the functional significance in lawmaking and law enforcement in Russia is determined; the effective implementation of the principles of law in the contemporary Russian legal practice is designated.
\end{abstract}

Keywords: Legal Basis, Principles of Law, Problems of Implementation of Principles of Law, The Implementation of the Principles of Law in Russia, The System of Legal Acts, Types of Principles of Law

\section{Introduction}

As G. Hochmayr ${ }^{1}$ states, the global integration in the legal and economic sphere of activity of contemporary states, more complicacy in different life areas are the main trends of contemporary civilization. There are many problems associated with the issues of modernization of public relations in the world; the suggested development models are often diametrically opposed. It is possible to combine existing knowledge and channel it rationally after learning the basics of the common values and common terminology. We think one of these contact points of contemporary national legal systems, as well as the basis for substantive improvement in public relations can be a detailed theoretical development and effective application of the principles of law in the context of the developed legal framework.

Appeal to the scientific literature in connection with the issue of general scientific analysis of using the principles of law in the legal basis of contemporary Russia allows noting the lack of this kind of research. The littlestudied topic of research is the theoretical analysis of the legal framework, as evidenced by the lack of basic monographs on the subject. In most cases, both in the domestic and foreign literature, the use of the mentioned categories is of applied ${ }^{2,3}$ inter-industry, sectoral nature, while scientists have long attempted to understand and formulate the definition of the category of "legal bases".

S. D. Mogilevsky, considering the legal basis of joint stock companies, determines it as a system of regulations containing rules governing the legal status of juridical entities, the procedure of their organization and activity"4. A similar view is held by S. I. Shishkin who determines the legal basis for the organization and activities of the legislative representative bodies of state power of the Russian Federation constituent entities by division into "the bases of formation, competence and organization

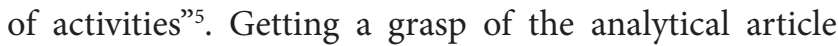
by N. Selivanova we can conclude that the legal bases include the definition of the legal status, the legal

\footnotetext{
${ }^{*}$ Author for correspondence
} 
regime of implementation of activities, accountability mechanisms ${ }^{6}$. After getting acquainted with the works by V. Abramov one can conclude that the legal bases establish in themselves a legal nexus of the entity possessing any rights and are defined as a set of rights and obligations ${ }^{7}$. The definition of the legal bases category is enhanced by this author by adding such characteristic as the interest in the implementation of the existing rights and scope of powers in relation to the implementation of one's own interest based on the law, or another act of law or contract.

Appeal to foreign literature allows noting the frequent use of the "legal basis" category both in everyday life and in scientific research ${ }^{1-3}$, the essence of which reduces to a common understanding of the legal basis as the legal framework, juridical basis, as a system of law acts regulating certain kind of public relations ${ }^{8-13}$.

Appeal to the analysis of the scientific literature on the general theoretical analysis of the principles of law, enables to notice a thorough addressing the issue in domestic and foreign literature at the general theoretical level and especially at the sectoral level ${ }^{14-16}$. Experts in the sectoral research point out the existence of a multi-level system of principles ${ }^{17-19}$.

Some authors suggest the existence of three levels of law principles ${ }^{20,21}$. A. V. Naumov highlights general principles (rule of law, democracy, humanism, internationalism), inter-industry principles (crime prevention, individualization of responsibility and punishment) and special ones (principle of subjective liability).

We believe that when considering this issue it is necessary to refer to the theory of law, where the scope of the principles of law activities forms the basis of their systematization criterion, which involves singling out common law, inter-industry and sectoral principles.

\section{Method}

- A formal dogmatic method of analysis. Using a formal dogmatic method involves the analysis of the regulations directly establishing the legal framework, principles of law, which allowed characterizing the formation of the categorical apparatus and the conceptual framework of these concepts, highlighting the logical, linguistic, terminological, conceptual features of their presentation, identifying interaction with other legal categories and concepts. The authenticity of research findings is based on the use of various methods of learning.
- A synergistic method. Using a synergistic method of research allowed, on the one hand, identifying regularities in the formation and functioning of the principles of Russian law, on the other hand, paying attention to the occasional positive (negative) factors of social reality that affect the mechanism of formation and change in the content of the principles under study.

- A historical method. A historical analysis method allows identifying and comparing existing ideas about the principles of law in the different stages of historical development, noting the basic laws of development, self-promoting Russian legal system.

- A comparative legal method. Appeal to a comparative legal method enables us to compare our current understanding of the principles of law in different countries, in order to determine their general and specific properties.

Along with the aforementioned methods this investigation relied on the universal principles of scientific knowledge (objectivity, comprehensiveness, historicism, the unity of theory and practice), the use of which allowed generalizing the knowledge about the contemporary Russian system of principles.

\section{Results}

As a result of the study, the following conclusions were obtained:

- Legal framework is a system of harmoniously interacting regulations ensuring consistent implementation of the principles and other legal means in order to achieve a socially beneficial result, providing conditions for the comprehensive individual development and the effective government action.

- The content of the legal framework involves determining: 1. The legal efficacy and functional purpose of the legal acts regulating public relations; 2 . The legal status of participants in the regulated legal relations; 3 . The regulation of activities that is, the subject of legal regulation, the principles of activity arrangement, the purposes of the legal regulation and legal means of exercise of powers.

- Legal bases are used to generally or specifically model desirable patterns of social development of public relations, to define the rules of conduct by fixing the regulations with a high degree of generalization: the rules performing the functions of guidelines, objectives, statutory regulations, legal means of exercise of powers, which in its entirety provides the ideological and moral and regulatory impact. 
- Considering the ensuing discussion regarding the categories of "legal principle" and the "principle of law" it is noted that in the first case, such properties of the principle are pointed out, which emphasize the common commitment to the ideals, bases, values that form the base of society. In the second case, the meaning involves the direct or indirect preservation of the basic ideas, laws or development trends, which determine the nature, content and procedure for application of state-sanctioned or established rules of conduct.

- The principles of law are the ideological and legal, scientifically grounded basis, synthesizing and reflecting social or class interests and values expressed in the law rules which form and develop the system of legal regulation.

- As the elements of the principles of Russian law are: 1. General legal principles, that is the basic ideas that form the system of sectoral and inter-branch principles of law, laying the basis for the regulation of social relations in a particular sphere of activity (the scope of the general law principles - law in general); 2. Inter-branch principles express the original sources characterizing the community and the specifics of separate allied areas of law. Such principles function in two or more areas of law; 3 . Sectoral principles determine original sources being implemented in the framework of one branch of the law and reflect its specifics.

- The content of the principles of law can be divided into two components evolving the nature of law: spiritual, moral and organizational and functional aspect. The first component based on the universally recognized moral ethical values, rules of conduct develops and strengthens their basic, fundamental ideas necessary to regularize relations in a certain field of activity (legality, oral nature, publicity, immediacy, etc.). The second part defines the fundamental ideas, core values, conditions for the use of legal means to ensure the attainment of spiritual and moral component in the mechanism of law-making and law enforcement (independence, procedural equality of citizens and organizations, competitiveness and optionality, "the right to be listened to and heard in court").

- The general analysis of the use of the principles of law in the legal basis context allows stating the absence of direct regulatory impact of the principles of law on a system of legal regulation, because the principles of law are not a priority in relation to the implementation of specifically defined regulations, which must conform to them; principles of law cannot be the basis for submitted enforcement act. Such an attitude to the principles of law underestimates their regulatory impact, reduces the effectiveness of legal regulation as a whole.

\section{Discussion}

In most cases, the implementation of the "legal basis" category is connected with the reference to a certain regulatory framework. Thus, the legal basis of the Government of the Russian Federation activity is determined by enumerating such sources as the Constitution of the Russian Federation, federal constitutional laws, federal laws and normative decrees of the President of the Russian Federation. For example, the Federal Law "On Migration Registration of Foreign Citizens and Stateless Persons in the Russian Federation" states that "the legal basis" for migration registration in the Russian Federation is formed by the Constitution of the Russian Federation, international treaties of the Russian Federation, federal constitutional laws, other federal laws and normative legal acts of the Russian Federation taken in accordance with the aforementioned normative legal acts. The Federal Law "On Combating Terrorism" points out that "the legal basis for counter-terrorism efforts is provided by the Constitution of the Russian Federation, generally recognized principles and norms of international law, international treaties of the Russian Federation ... and other federal laws, normative legal acts of the President of the Russian Federation, laws and regulations of the Government of the Russian Federation and regulatory legal acts of other federal bodies of state power taken in accordance with the aforementioned normative legal acts". Many other documents that use this approach can be mentioned as an example.

At the same time other legislator approaches in determining the legal basis can be seen. Thus, recognizing the legal basis for the gasification development in the Russian Federation, the legislator says that it is the development "based on long-term balance of gas production and consumption, the federal, interregional and regional programs adopted in the prescribed manner for housing and utilities infrastructure, industrial and other organizations gasification". The procedure for these federal programs development and implementation with account of the balance prospects is, in point of fact, the 
implementation principle determined by regulations. We note that, such balance development procedure has not been adopted to date, that is, the law contains a principle that has not received its normative procedure for implementing, but despite this is an existing law, since, in practice, "the balance prospect" is defined as "financing federal programs for the provision of gas supply for the housing and utilities infrastructure, industrial and other organizations .... at the expense of the federal budget, the Russian Federation certain subjects' budgets and the other sources not prohibited by the Russian legislation"22.

More clearly the implementation of law principles can be traced in the context of determining the legal basis for legislation on financial bases for local self-government, which notes that " 1 . Local government authorities perform functions on the local finances organization in cooperation with financial institutions operating on the municipal territory and beyond it. 2. Local governments contribute to the development of local financial markets, local financial and credit institutions". A similar approach is used to consolidate the legal basis of martial law, which acts as "the Constitution of the Russian Federation, federal laws and other normative legal acts of the Russian Federation adopted on its basis, as well as the generally recognized principles and norms international law and international treaties in this area in the Russian Federation".

The legislator took a thorough approach to the legal framework characterization in the Federal Law "On General Principles of Organization of Local SelfGovernment in the Russian Federation", where the local government legal framework is presented as an interrelated system of normative legal acts and regulations governing the local government organization and activities, its purpose as an institution in a common management system.

The system of regulations and standards on local government is presented in the following logical sequence.

Firstly, the legal acts and regulations are divided into three groups. The first group consists of federally important regulatory legal acts: The Constitution of the Russian Federation, federal laws, normative legal acts of the President of the Russian Federation, normative legal acts of the Government of the Russian Federation, other normative legal acts (for example, decisions of the State Duma having a regulatory character, decisions of the Constitutional Court of the Russian Federation and so on). The second group consists of regulatory legal acts of constituent entities of the Russian Federation. They include the Constitution, statutes, laws and regulatory acts of the state executive authorities and the Russian Federation officials. The third group consists of regulatory legal acts adopted in the local government system. These include decisions adopted by a local referendum, public gathering, those adopted by local self-government and government representative and executive bodies, officials of local self-government authorities. For example, the municipal formation statutes, regulations on budgetary system and process, on the local government structure, on the municipal property management arrangement are also normative legal acts which constitute the local government legal framework.

Secondly, the normative legal acts are divided into the laws and by-laws according to the legal force. The laws have the highest legal force in relation to the by-laws. The by-laws should not conflict with the law. If the bylaw normative act conflicts with the law, it is not effective to the extent contrary to the law and must be brought in line with the law. Laws are issued by the Federal Assembly of the Russian Federation, the legislative bodies of the constituent entities of the Russian Federation. The main place in the system of law is taken by the Constitution of the Russian Federation, on the basis of which federal laws, the laws of the subjects of the Russian Federation, as well as the by-laws of all levels of state and local government authorities are issued. This means that regulations and other acts adopted by the President of the Russian Federation, the Government of the Russian Federation and other federal agencies must comply with the Russian Constitution and the federal law. The same ratio of law and by-law must be observed in the constituent entities of the Russian Federation as well. In addition, all the laws and by-laws of subjects of the Russian Federation must not contradict provisions in the Constitution, federal laws and regulatory legal acts adopted by the President and the Government of the Russian Federation. It is out of the question that the acts of the President and the Government of the Russian Federation do not come into conflict with the provisions in Constitution and federal laws.

The lawmaker introduces mandatory compliance with the principle of normative legal acts subordination in the use of legal bases which regulate relations in the local self-government system. This principle is one of the main conditions ensuring an adequate management of establishment and development of the local self- 
government institute, whereas local government regulations must be a single, coherent mechanism for concerted action across the state. According to Article 7 of the Federal Law "On General Principles of the Organization of Local Self-Government in the Russian Federation", the local government is carried out in accordance with the Constitution of the Russian Federation, the mentioned Act and other federal laws, constitutions, charters of subjects of the Russian Federation, the laws of the subjects or the Russian Federation. Further, the law sets the subordination standard of regulations of the subjects of the Russian Federation to the Federal level regulations. Article 7 Part 2 of the Act states as follows: "The legislative regulation of local self-government issues is carried out in accordance with the Constitution of the Russian Federation and this Law by the subjects of the Russian Federation". In Part 3 of the same article the rule on the consistency of other laws establishing municipal law rules with the Constitution and basic Federal Law "On General Principles of the Organization of Local Self-Government in the Russian Federation" is introduced. This means that all the adopted regulations should not contradict not only to the Constitution, but also to the Federal Law. Consequently, the RF Constitution and federal laws are the foundation upon which all law-making public authorities' activity in the area of local self-government is built.

Thirdly, legal acts are divided into special, fully dedicated to the regulation of all or some relations in the local government system and those containing certain standards relating to local government. Special laws are as follows: Federal Law "On General Principles of the Organization of Local Self-Government in the Russian Federation", Federal Law "On the financial basis of local self-government in the Russian Federation", Federal Law "On Ensuring the Constitutional Rights of citizens of the Russian Federation to Elect and be Elected to the Bodies of Local Self-government", laws of the subjects of the Russian Federation on local government, on elections to the local self-government, on local referendum, on territorial selfgovernment, on public meetings (gatherings), on election of the local government officers, on the municipal property formation order and others. The rules governing certain types of relations in the local government system are found, for example, in the Constitution of the Russian Federation, in a number of federal laws, constitutions and charters of subjects of the Russian Federation and in separate laws of the Russian Federation without a special mission for the local government. The Law of the Russian Federation "On Subsoil", the RF Law "On Education" and others can be referred to this group.

As we can see, the legislator using the "legal bases" category does not always unambiguously understand its content but is governed only by the need in solving very general or individual separate issues of the law enforcement practice without creating unified bases for the legal matter self-organization system in particular areas of life, thereby involuntarily diminishing the scientific and practical potential of the category.

The national and foreign characteristics listed above do not give the exact definition of the "legal basis". However, the approaches provided by the legislator and scientists allow distinguishing the similarity in understanding this category as a complex of legal acts that fulfill statutory regulation through establishment and administration of the law.

In reliance upon the established perceptions, we consider the legal basis to be a system of legal acts that ensure consistent implementation of principles and other legal means for the purpose of achieving socially beneficial result.

The suggested definition makes it clear that the essence and social use of the legal bases are specified in such legal phenomena as legal purposes, means and legal principles.

The juridical science has always paid attention to the importance of categories "principles of law", "principles of legal regulation". Even L. S. Yavich wrote that the better the principles or law and legal regulation will be elaborated, the sooner the combination of stability and mobility of the legal forms will be achieved ${ }^{23}$.

The use of the "principle" category originates in the $18^{\text {th }}$ century, from French and German languages, which, in turn, borrowed it from Latin "principium" denoting 'beginning, base'. In its etymological meaning, the notion of "principle" is a base, beginning, foundation, guiding idea, and basic rule of conduct. As long ago as in the ancient times they stated: "the principle is the most important part of all" (principium estpotissima pars cujuque rei).

Addressing to philosophy allows marking the usage of the notion "principle" in two senses: subjective - as the main provision, premise; objective - as a starting point. Aristotle considered principle in the objective sense as the ultimate unit, i.e. the basis, on which something exists or 
will exist. I. Kant, considering principle in the subjective sense, pointed out constructive (only for empirical usage) and regulative (only for transcendental or practical usage) principles ${ }^{24}$. In logic principle is the central idea, foundation of a system presenting generalization and distribution of any provisions, the area, from which this principle is abstracted ${ }^{25}$. Hence, in the most general terms, the principle expresses the theoretical generalization, a governing idea, an initial position of any phenomenon (teaching, organization, activity, etc.) underlying any system and expressing the most significant laws of its development.

The word "principle" means the basis, a governing idea, an initial position of any phenomenon (teaching, organization, activity, etc.). In legal science, principles formulated by legal scholars appear as fundamental ideas and ideals reflecting achievements of the legal thought, practical experience, objective laws of society development. Legal principles constitute an integral part of scientific and professional legal consciousness, legal policy and are not always mandatory for subjects of law. Besides, there are separate principles of law, which should be understood as initial regulatory governing frameworks (peremptory requirements) determining the general direction of legal regulation of social relations. As correctly noted by V. G. Rumyantseva and Yu. Ye. Shyryayev, "the fundamental ideas of the law do not act as an arbitrary construct of human mind, but as a special form of expressing objective social laws. By fixing the required and essential relations existing in society and law in their content they enable to establish such a social relations order, which contributes in their strengthening and development to the greatest extent" 26 .

M. I. Baytin emphasizes the significance of principles for formation of legal bases of social relations noting that the "principles of law are initial defining ideas, provisions and aims, which constitute the moral and organizational basis for origin, development and functioning of law"27, and also they lay foundation for shaping dynamics and force of law, determine the social nature of law.

Being unable to suppress the sense of scientific curiosity, it is worthwhile touching the polemics regarding the dispute around understanding of such categories as "legal principles" and "principles of law" because each of these influences on the content of legal bases.

A number of scientists believe that legal principles should positively receive regulatory confirmation; others hold that legal principles express the "spirit" but not the "letter" of the law, and do not necessarily have to be directly defined in regulatory legal acts, but should be determined by legal rules and the law in general.

As a matter of fact, the authors propose delimiting the categories of "legal principle" and "principle of law" by the criterion of normativeness, or formal confirmation of principle in the regulatory legal act (implying the normativeness of the latter). The developments of the dispute do not currently allow distinguishing any positive criteria and grounds for using some legal principle or other, whether at various stages of the lawmaking activity, or in law enforcement, which are the crucial stages of functioning of the country's legal system.

The settlement of the existing discussion is seen in comprehensive analysis from the morphological standpoints of the meanings of the "legal principle" and "principle of law" categories.

In the first case, addressing to the word "legal ..." indicates to properties of principle where dedication to the common ideals, beginnings and values that form the core of the society's viability are highlighted. In order to clarify the understanding, we should refer to the Constitution of the Russian Federation, where the preamble describes such legal principles as "equality and self-determination of peoples". Establishing such categories as legal principles is determined by their general recognition, since theoretically they are shared almost by the whole progressive, global, civilized, democratic community.

In the second case, the meaning of the notion "principle of law" reflects consolidation, directly or indirectly, of the main ideas, laws, or tendencies of the development that determine the essence, content and order of using the code of conduct that is established and authorized by the state. Such principles include: freedom, supremacy of law, justness, democracy, humanism and so on.

The principles of law and legal principles are in the mutual dependence, they complement and develop the nature and essence of each other, carry individual features of the each other being reflected in objective properties of the legal foundations determined by the laws of cultural, political, social and economic development of the society, interests, needs and contradictions of various groups and strata of population. Owing to the principles of law, the subjective perception of people, their moral and legal views, feelings and requirements expressed in various teachings and theories aimed at law consciousness are embodied in the legal foundations.

The principles of law and legal principles are 
interdependent, complementary and develop nature and essence of each other, carry the individual features of each and are reflected in the objective properties of the legal framework arising from the laws of cultural, political, social - economic development of society, interests, needs and contradictions different groups, segments of the population. Due to the principles of law embodied in the legal basis of the subjective perception of the person, his moral and legal views, feelings, claims denominated in various doctrines, theories of legal directions.

The principles of law represented in the system reflect the important, essential in the legal basis, namely the main trends of development, what legal basis should be directed at, where they are directed at. To make our ongoing research complete and to understand the importance of the influence of the principles of law on the formation and implementation of the legal framework one should consider the impact of the principles of law in general on the legal framework content that is stipulated by the need for more in-depth and comprehensive study of the principles from the standpoint of determining the place of each principle in the system, as well as to identify the most perfect mechanism for matching the specific regulations to requirements of not a separate principle, but their totality. In this regard, M. L. Davydovis right noting that "the formation of a system of principles contributes to a higher level of the law conceptualization"28.

According to the definition given in the Philosophical Encyclopedic Dictionary, the system is "the union of a variety in one and clearly dissected whole, the elements of which occupy the appropriate places in relation to the whole and the other parts"24.

The system of the principles acts as a complex hierarchical formation, which highlights different levels with different types of legal relationships, "the various essential aspects of law and scopes of manifestations of this nature are reflected" ${ }^{\prime 2}$. Moreover, such a structure of the system is due to the fact that its elements, in turn, may also be considered as special systems $\mathrm{s}^{30}$.

Experts in sectoral sciences point out the existence of multilevel system of principles. Thus, G. B.Vittenberg singled out two groups of basic principles of criminal law: the general legal principles, which include public danger of punishable offense, legality, internationalism, democracy, humanism and specific criminal law principles: crime prevention, personal responsibility only of the offender, comprehensive protection of an individual, individualization of responsibility and punishment, public participation in the fight against crime ${ }^{31}$.

Among the general principles N. I. Zagorodnikov referred to democracy, rule of law, humanism, internationalism, and among special ones - to all-round protection of the achievements of working people, the principle of personal and fault liability, the participation of the people in the application and implementation of rules of criminal law, crime prevention, the coincidence of negative criminal law and moral evaluation of acts recognized ascriminal ${ }^{32}$.

Some authors say that there are three levels of law principles. A. V. Naumov highlights the general principles (rule of law, democracy, humanism, internationalism), inter-industry (crime prevention, individualization of responsibility and punishment) and special (principle of subjective liability) ${ }^{21}$.

We believe that while considering this question it is necessary to turn to the theory of law, where the scope of the principles activity is regarded as criteria for their systematization, which involves singling out the common law, inter-industry and sectoral principles of law (S. S. Alekseyev, M. I. Baytin, A. M. Vasiliyev, N. I. Matuzov, L. S. Yavich, etc. $)^{27}$.

Let us start with the general principles that cover the whole legal framework as applicable to the formation of the legal basis for themselves, as well as all aspects of the impact of such a framework, promote the unity and stability of the system of legislation formed by the legal framework.

As the literature on the research studied by us demonstrates, the question of including the general principles to the system of sectoral principles of law and their relationship is disputable.

So, S. G. Kelina and V. N. Kudryavtsev believe that sectoral principles do not exist in pure form. In their view, the general principles apply to all (or almost all) areas of law. In every industry these principles are manifested in its own way which is caused by the specifics of the subject and the method of regulation, as well as the specifics of the tasks and functions performed by such legal industry ${ }^{33}$.

According to V. Maltsev, classification of principles of criminal law into general and special, basic and nonbasic, common law (general), and regulators "are mainly doctrinal, quite scholastic in nature and therefore cannot be directly used in it". The author notes that "it is on the basis of areas of law ... there is a whole spectrum of 
principles of law, which is then highlighted in the theory of both general and inter-industry principles. Therefore, for example, criminal law principles rather not follow the general principles of law, but "flow into" them; they are not formed, but form the latter" 34 .

In our view, the general legal principles have an enormous impact on legal practice, as they influence upon the formation and implementation of the legal framework by the determination of the whole process of legal regulation of social relations within the subject of regulation of legal bases. This is due to the fact that these principles have their origin in the form of a structural element of a more general concept than a system of principles of the specific branch of law, namely, the system of the principles of law in general.

In its turn, sectoral principles provide the refraction of the general principles of law through the prism the subject and method of regulation of a particular field of law, which allows general legal principles of law to be applied in legislative practice and enforcement in the context of the legal framework. This can be seen in the principle of legality, which manifests itself in criminal law in that criminal act and its punishability and other criminal and legal consequences are determined only by the Criminal Code of the Russian Federation; and the application of criminal law by analogy is not permitted (Art. 3 of the RF Criminal Code). However, in the most general definition the law is an unconditional execution of laws, regulations and court decisions by all state bodies, officials and citizens, as well as the protection of the legitimate interests and rights of citizens, the possibility of judicial review of the actions of officials.

However, it should be noted that the contents of the general legal principle must necessarily be reflected in the specific field of law, otherwise the meaning and value of law is undermined reducing its legal effect. This circumstance is achieved by a thorough study of sectoral and inter-industry principles.

Thus, it should be recognized that the general legal principles in the context of the legal framework create a system of sectoral and inter-industry principles of law, laying henceforth the legal basis for the regulation of social relations in a particular field of activity, as the scope of the general principles is the law in general.

In the works by foreign researchers it is noted that the system of general principles because of their fundamental nature is still prevailing over the value of the official regulations, which implies the possibility of direct implementation in law enforcement, with a clear understanding of their compliance ${ }^{35-38}$.

It is a very difficult and important question about the content of inter-industry principles of law, which according to A. L. Zakharov present a common idea to two or more branches of the law, reflecting the patterns and connections of public relations development, regulatory enshrined in positive law, guiding the legal regulation and determining the nature and social purpose of law ${ }^{39}$.

Most authors do not include them into the system of principles considered by us, in our opinion, this is not correct, because it is difficult to disagree with the fact that the inter-industry principles, as well as sectoral ones, are derived from common principles, develop and concretize their provisions in relation to the two or several branches of the law.

If we speak about the specific content of the principles in the context of the legal framework, the latter cannot simply be listed, but should have their justification in the form of a conceptual framework, developing understanding of the legal foundations with informational moral and formal legal point of view. According to the previously proposed classification principles of law are subdivided into common law, which in their turn are divided into ethical or moral, and organizational principles.

The moral-ethical (honest) component of the general legal principles of law forms the spiritual-moral foundation, the initial sources that provide information impact on the normative content of the legal framework. The second group of the general principles (organizational principles) is tightly linked to the first one because, on the one hand, it determines the organizational and procedural implementation of the moral-ethical component of the legal framework aimed at ensuring the role of the latter as a special regulator of social relations.

These principles may be enshrined in international and national declarations, constitutions, laws, and may also be derived from the law content and spirit of any particular country.

The moral-ethical (honest) principles of the legal foundations of the modern Russian society are basic fundamental human and civil rights enshrined by the Universal Declaration of Human Rights and developed in international and domestic documents. Such laws are as follows: freedom, equality, the right to life, the right to 
private and other forms of ownership, security, dignity, justice, the protection of the family, the protection of human rights and freedoms as the main value and the duty of the state.

Organizational principles of the legal basis express the fundamental values that the entities in the lawmaking and enforcement activities should be guided by. The latter must start from the observance of moralethical principles worked out in the legislation, as well as enshrined in public international law. The following principles can be proclaimed as such: obligatory respect for the rights of the individual and the rights themselves; ensuring the procedural rights and guarantees in bringing to justice; legal certainty and security according to which the content of the legal framework must be clear and predictable for all entities; the principle which does not allow giving retroactive effect to measures, aggravating the situation of persons in comparison to the current legal regulation should be included here; the widespread implementation of value-oriented human dignity, freedom, democracy, equality, pluralism, tolerance, the rule of law, solidarity and non-discrimination as well as respect for human rights.

Following the general principles of law the interindustry and sectoral principles specifically developed by separate legal sciences certainly contribute to the content of the legal basis.

Inter-industry principles of law are determined by theoretical analysis of principles common to several branches of law which have distinctive traits due to the peculiarities of the subject and method of legal regulation. In the context of the legal basis the abovementioned principles express the uniqueness of branches of law defining feature of the content of the latter in the legal system highlighting the specificity of their inherent principles.

In the content of inter-industry principles there are two components developing the nature of the legal basis: the ideological, organizational and functional aspect. The first component, being based on the moral-ethical principles of common law and developing them, sets out the basic, fundamental ideas of the legal basis for branches of law similar in subject and method of legal regulation. They include: the rule of law, oral nature, publicity, immediacy and others. The second component determines the fundamental ideas, core values and conditions for the use of legal means to ensure the attainment of spiritual and moral component in the mechanism of lawmaking and law enforcement activities at the sectoral level. Independence, procedural equality of citizens and organizations, competitiveness and optionality, "the right to be listened and heard in court" $"$ and others can be identified as such principles.

Inter-industry principles of law interpenetrate, enrich and concretize deeply the content of ideological, organizational and functional elements. The significance of this relationship is so great because it can have a great impact on the formation of the legal basis in the spirit of democratic character and further progressive development. This is the principle of the presumption of innocence. This principle has received its official and constitutional recognition of natural law school doctrine rooted in the Declaration of Human Rights, a logical consequence of which is the consolidation in the Constitution of Russian Federation principles that the accused is not obliged to prove his/her innocence (paragraph 2, Art. 49) and disposable doubt shall be interpreted in favor of the accused.

The content of branch principles carries a reflection of the fundamental theoretical and legal ideas in the form of principles of development of a specific branch of law, as well as basic organizational and regulatory principles of legal regulation mechanism ${ }^{41-43}$. All of the above gets its consolidation in the form of specific legal norms, principles, i.e. actually materialized in the legal framework.

These principles provide the basis for the development and implementation of inter-industry and sectoral principles of law in practice. For example, Art. 3 of Tax Code of the Russian Federation states: "Legislation about taxes and fees is based on the recognition of universality and equality of taxation. In establishing the tax, the actual ability of the taxpayer to pay the tax is taken into account. Taxes and duties cannot be discriminatory and applied on the basis of different social, racial, national, religious or other similar criteria”.

Thus, the principles fixed in the legal bases are developed and concretized in the specific rules of conduct, being ideological and legal basis of such rules, the criterion of their ordering. At this level, the principles are objectified in the legal system without losing their ideological nature relying on coercive means of legal pressure regulated by sanctions of legal standard. In this regard it is correct to be noted that principles erected in the legal basis are 
ideological and legal, scientifically sound basis on which the system of legal norms of any society is formed and developed. In an extended sense, we can note that they synthesize and reflect social or class interests which are specified and developed in the rules and goals of the legal system functioning. In our opinion, this fact is a strong argument for the theoretically important conclusion that a change of ideas - the principles of the legal basis means changing historical type of law on which the legal system and all social relations are built.

In comparison with the general legal and sectoral principles of law, the ideas - the principles built-in the legal basis in the branch of law have greater mobility, because their content can be changed, added or processed on the basis of the law enforcement results.

The second, the organizational and regulatory principles are aimed at identifying ways of application of the legal regulation facilities for the implementation of ideas - principles in law enforcement. For the legal bases of modern Russia developing towards the formation of a civilized civil society and law-bound state the mechanisms of incentives and restrictions, rewards and punishments should be more frequent resorted to. It should be noted that these standards - principles should determine the meaning and content of all sectoral mechanism for the regulation of law, i.e. if the content of the legal framework for the regulation of relations is determined by the need to use the principle of incentives and constraints, other ways should not receive their implementation. Compliance with the latter provides the sequence of the implementation of the common law, inter-industry and sectoral principles of law in the maintenance of the legal basis, which is much closer to the realization of the law practice.

The general analysis of the use of the principles of law allows noticing the lack of real regulatory value in the context of the legal basis. The principles of law do not have a priority in relation to the specific rules of law, which must conform to them; principles of law cannot be the basis for submitted enforcement act. Such an attitude to the principles of law underestimates their regulatory impact, reduces the effectiveness of legal regulation in whole.

\section{Conclusion}

In modern Russia the principles of law occupy a special place in the system of legal categories because they act as a link between the philosophical and legal-dogmatic interpretations of the law. In the principles of law, the essence of law is directly expressed, its content is specified. It is the principles of law that underlie the specific regulatory requirements defining the relationship between the various entities that provide consistency and stability and, most importantly, a true legal nature of the adopted legal acts.

The importance of the principles of law is determined by the traditional attention to them on behalf of jurisprudence and practice. In the theory of law principles are generally regarded as the ideas implemented by statutory regulation and enforcement practices. These ideas terminologically expressed in similar terms (democracy, humanism, internationalism, legality, justice, scientific validity, etc.), were attached to different content in different historical periods. But the main thing is that they have always been considered as nothing more than good intentions addressed by the science of law-making and law enforcement to the practice. The practice, in turn, also perceived the principles of law exceptionally on paper only. All major legislative acts (mainly codified) were introduced by articles (heads), where the principles, upon which the regulation of the respective sphere of relations is based, were listed. But it was limited to that. Such provisions were considered as general declarations with only moral and political significance. Meanwhile, the practice of western democracy countries, international and supranational regulation demonstrates completely different trends. There principles of law are contributed to a real regulatory value, the priority regarding the regulatory requirements that have to meet them; principles can be the basis of the judgment. Such an attitude to the principles of law requires the presentation of knowledge about the implementation of these principles in the context of the legal framework.

\section{References}

1. Hochmayr G. Applicable Law in Practice and Theory Interpreting Article 21 of the ICC Statute. Journal of International Criminal Justice. 2014; 12(4):655-79.

2. Horton D. Wills Law on the Ground. Ucla Law Review. 2015; 62(5):1094-155.

3. Jackson VC. Constitutional Law in an Age of Proportionality, Yale Law Journal. 2015; 124(8):3094-196).

4. Mogilevsky; 2014. 
5. Shishkin SI. The Legal Basis for the Organization and Activities of Legal (Representative) Bodies of State Power of Subjects of the Russian Federation. Siberian Law Herald. Novosibirsk. 2002; 3:18. [in Russian].

6. Selivanova N. Legal Basis for Running a Small Business (to Lawyer/Analytical Articles). 2013. Available from: http:// www.garant.ru/ [in Russian]

7. Abramov V. Insurable Interest: The Legal Framework and Arbitration Practice. Financial Newspaper. Moscow. 2014; 9:36. [in Russian].

8. Bruce JW. Legal Bases for the Management of Forest Resources as Common Property. Land Tenure Center. University of Wisconsin-Madison; 1996.

9. Halderman, John W. Legal Basis for United Nations Armed Forces. J Intl L. 971. 56 Am; 1962.

10. Mootz Francis J. Ontological Basis of Legal Hermeneutics: a Proposed Model of Inquiry Based on the Work of Gadamer, Habermas and Ricoeur. Toronto. 1988; 10(1):77-90.

11. Mayor Houston Has No Legal Basis to Stop 21-Story Ashby High-Rise. Will Settle Suit. 2015. Available from: http://www.yourhoustonnews.com/west_university/news/ mayor-houston-has-no-legal-basis-to-stop--story/article_ fca0d09c-9cdb-593f-94e5-769176fb10e7.html

12. Potter MA et al. Connecting Silos: The Legal Bases for Public Health Emergency Response in Pennsylvania Journal of Public Health Management and Practice. 2005; 10(1):7790.

13. Samuels W. Economy as a System of Power and its Legal Bases. The Legal Economics of Robert Lee Hale. The University of Miami Law Review. 1973; 9(3):67-80.

14. Sunstein CR, Vermeule A. Libertarian Administrative Law. University of Chicago Law Review. 2015; 82(1):393-473.

15. von Bogdandy A. Common principles for a plurality of orders: A study on public authority in the European legal area. Icon-International Journal of Constitutional Law. 2014; 12(4):980-1007.

16. Watts KA. Constraining Certiorari Using Administrative Law Principles. University of Pennsylvania Law Review. 2011; 160(1):1-68.

17. Anker HT, de Graaf K, Purdy R,Squintani L. Coping with EU Environmental Legislation-Transposition Principles and Practices. Journal of Environmental Law. 2015; 27(1): 17-44.

18. Cook PJ, Ludwig J. Principles for Effective Gun Policy. Fordham Law Review. 2004; 73(2):589-613.

19. Epstein RA. From Natural Law to Social Welfare: Theoretical Principles and Practical Applications. Iowa Law Review. $2015 ; 100(4): 1743-72$.

20. Krieger; 2013.

21. Naumov AV. Russian Criminal Law. Textbook. Norma. 2014; 582. [in Russian].

22. Keil A. Commentary to the Federal Law of March 31, 1999 N 69-FZ On Gas Supply in the Russian Federation. Monograph. LLC The new legal culture. 2007; 386 [in Russian].

23. Yavich LS. General Theory of Law. Leningrad: LGU Press; 1976.
24. Philosophical Encyclopedic Dictionary. Norma. 2015; 435. [in Russian].

25. Logic dictionary-reference book; 2013.

26. Rumyantseva VT, Shyryayev YY. Notion of the principle of law in the context of the law making process. History of State and Law. 2006; 8:4-5.

27. Baytin MI. The Essence of the Right (a Modern Regulatory Legal Thinking on the Verge of Two Centuries). Monograph. Company LLC PH The Law and the State. 2005; 226 [in Russian].

28. Davydov; 2013

29. Yakushin VA. Problems of subjective imputation in criminal law. Extended abstract of Doctoral thesis in law, Moscow. 1998; 13 [in Russian].

30. Sadovskiy VN. The Basis of General Systems Theory. Monograph. Science. 2014; 286 [in Russian].

31. Vittenberg GB. The Development of the Basic Principles of the Soviet Criminal Law in the new Criminal Code of the RSFSR. Jurisprudence. Leningrad. 1962; 4:90 [in Russian].

32. Zagorodnikov NI. The Principles of Soviet Socialist Law. The Soviet State and the Law. 1966; 5:66. Moscow [in Russian].

33. Kelina SG, Kudryavtsev VN. Principles of the Soviet Criminal Law. Monograph. Politizdat. 1988; 262 [in Russian].

34. Maltsev VV. Principles of Criminal Law and Their Implementation in Law Enforcement. Monograph. Norma. Saint Petersburg. 2014; 186 [in Russian].

35. Fredriksen HH, Franklin CNK. Of pragmatism and principles: the eea agreement 20 years on. Common Market Law Review. 2015; 52(3):629-84.

36. Gordon B. Tax Competition and Harmonisation under EU Law: Economic Realities and Legal Rules. European Law Review. 2014; 39(6):790-811.

37. Oyetayo Y. Principles-Based Regulations: A Model for Legal Reform in the Nigerian Insurance Industry. Journal of African Law. 2015; 59(1):64-84.

38. Rock EB. Corporate Law Doctrine and the Legacy of American Legal Realism. University of Pennsylvania Law Review. 2015; (163)7:2019-53.

39. Zakharov AL. Cross-Industry Principles of the Law. Extended abstract of PhD in law dissertation. Kazan. 2013; 7. [in Russian].

40. Sherstyuk VM. On the Principles of Arbitration Proceedings. Household and the Law.Moscow. 2004; 6:52-5 [in Russian].

41. Kingsbury B. The Concept of Law in Global Administrative Law. European Journal of International Law. 2009; 20(1):23-57.

42. Lenaerts K. In the union we trust: Trust-enhancing principles of community law. Common Market Law Review. 2004; 41(2):317-43.

43. Mendelsohn B, Brush J. The Duties to Correct and Update: a Web of Conflicting Case Law and Principles. Securities Regulation Law Journal. 2015; 43(1):67-89.

Sakharov AB. About the Socialist Principles of Criminal Law. Jurisprudence. Leniningrad. 1969; 4:56. [in Russian]. 